\title{
Oral tradition in the study of ulayat land disputes in West Sumatra
}

\author{
SUSI FITRIA DEWI
}

\begin{abstract}
Land is a society's potent symbol of wealth, social power, and culture. A long time ago, when extensive jungles and forests still abounded, there were probably no serious conflicts over land ownership. Groups were free to roam about and to open up land to extend their farming area in accordance to their needs. Groups in society marked the land they had cultivated to proclaim their ownership. These marks could be very simple and could simply be a tree, a big stone, or a piece of iron hammered into the soil, or they used the physical condition of the land itself such as rivers, lakes, hills etcetera as borders to distinguish their land from that of others. Minangkabau traditional society never recorded these borders in writing on paper, leaves, or stones or any other means as many peoples in other parts of the world do. Rather, they deemed it sufficient to use natural symbols to demarcate the important agreements they had made between them orally.

KEYWORDS

Oral tradition, pantun, syair, ulayat land, conflict, Nagari, Minangkabau, West Sumatra.
\end{abstract}

\section{INTRODUCTION ${ }^{1}$}

As in other regions in Indonesia, before having been introduced to writing, the system of inheritance regulations of the Minangkabau in West Sumatra was transmitted and preserved orally. Oral tradition, like narratives, legends, anecdotes, pantun, and syair, as well as artistic body gestures and dances continue to exist and have remained part of the way of life up to the present day. Based on data found on www.tradisilisan.org, ${ }^{2}$ I define oral tradition as the total

1 This article based on the paper that was presented at the Seminar Antar Bangsa Tradisi Lisan Melayu, Klub Danau Golf, Universiti Kebangsaan Malaysia, Bangi, Malaysia, 17-18 November 2009.

$2 \quad H t t p: / /$ tradisilisan.blogspot.com/ (accessed 27-11-2009, $5.38 \mathrm{am}$ ).

SUSI FITRIA DEWI is lecturer at the Faculty of Social and Political Sciences of Universitas Negeri Padang (UNP). She is pursuing her doctoral degree at the University Kebangsaan Malaysia (UKM) at the Institute of the Malay World and Civilization (ATMA). Susi Fitri Dewi may be contacted at: susifd@yahoo.com.

(C) 2010 Faculty of Humanities, University of Indonesia 
of sayings and discourses as the locus of expression, and of the compilation of knowledge, and for the familiarization with norms, values, attitudes, and aesthetics. The sayings may be in the form of pantun, pepatah (old proverbs), gurindam (poems made up of two rhyming lines of equal length), sayings, and literary works containing wise lessons and guidance for a good and happy life. Something oral or a saying can be considered part of a tradition when the words contained in them have turned into guidelines for how to live, to act, and to behave and have been transmitted from one generation to the next. The superiority of the oral over the written tradition is the atmosphere in which it is transmitted, which written tradition cannot possibly approach even when it has been provided with semiotic marks. According to Mukhlis PaEni, oral tradition is closely intertwined with a society's cognitive system, such as its customs, history, ethics, and genealogy and knowledge systems (see Note 2).

\section{ORAL TRADITION IN WEST SUMATRA}

Based on the definition of oral tradition presented above, literature, customary law, and the law of words are part of the oral tradition in West Sumatra. This oral tradition was in use in the beginning of literary life in West Sumatra and exists until this day. Stories and customary law were transmitted by village heads (penghulu) to clan heads (ninik mamak) and from them to other relatives in an oral manner (from mouth to mouth). Apparently, the people continue to adhere to this oral, customary transmission system. They not only continue to adhere to it, but the Minangkabau highly appreciate their oral tradition and it does not only reflect their customs, history, and genealogy system, but also serves as an efficient instrument to control the overall behaviour of the Minangkabau people.

\section{THE SIGNIFICANCE OF ORAL TRADITION}

Among the Minangkabau, one type of oral tradition is popularly known as pasambahan and consist of pepatah and pantun. They are invariably narrated during traditional ceremonies and events like weddings, funerals, and at the occasion of the inauguration of village heads (batagak penghulu). Similarly, pepatah and pantun function in daily life as means of moral admonition, advice and suggestions, as well as teasing. Pepatah are considered much more effective than directly and clearly conveying messages. This figurative way of speech takes account of the sensitivity of feelings and is an expression of the high regard Minangkabau culture has for language. A person is allowed to call him/herself a good Minangkabau, if he/she is able to compose pepatah and pantun. A person who conveys his messages by means of the oral tradition is considered wise and the person who listens to him is considered astute. The higher a penghulu's knowledge of pepatah, pantun, and customary law, and the more he has committed to memory, the more society will respect him. This fact alone proves that Minangkabau society is truly characterized by oral tradition (Bakar et al. 1981: 6-7). Chart 1 illustrates the relationship between Minangkabau society and oral tradition. 


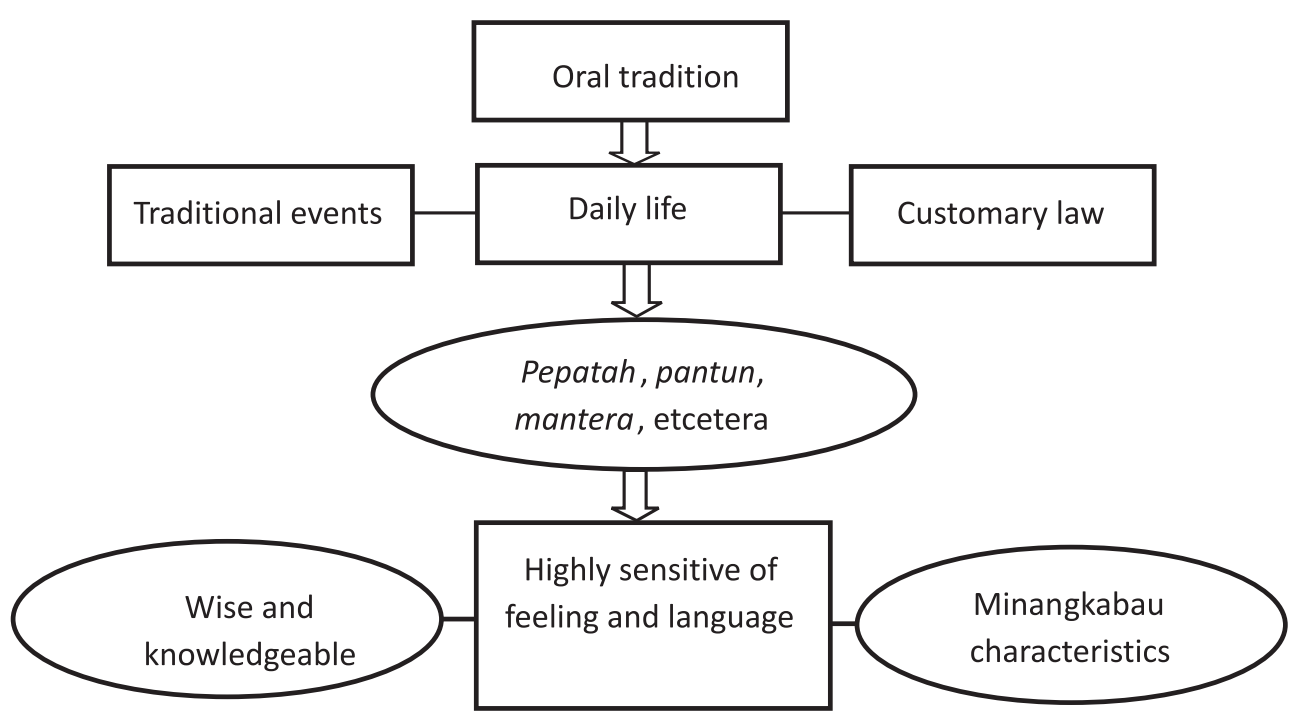

Chart 1. The interrelation between Minangkabau society and oral tradition.

\section{THE CLASSIFICATION OF ORAL TRADITION}

Oral tradition may be found in the form of proverbs (pepatah, petitih), and customary law or sako as it is known in Minangkabau's tradition. Sako is defined as an intangible resource which is transmitted from generation to generation to every member of a Nagari and of Minangkabau society as whole (Amir M.S. 1997: 94). Based on my research, there are two oral traditions: literary oral tradition and oral tradition in customary law. Both can be analysed through martabat kata, langgam kata, sifat kata, and kurenah kata. Martabat kata may be analysed at the level of the words, based on the wisdom contained in them and on their meaning. Kato nan sabana kato (a word that is truly a word), means a word that contains a high level of wisdom so that it can be used as a guideline in life. Meanwhile, kato nan takato katoi (words merely used for easy communication) are insignificant because they are only the language of jokes. Langgam kata refers to politeness in language and to adjusting the use of language when talking to others to their social status. Kato mandaki (the word mendaki) means that the person addressed is of a higher social status. Kato manurun (the word menurun) means that the person addressed is of a lower social status. Sifat kata means that words are chosen to elicit a certain reaction with the listener. The words kato mancari kawan (words for finding friends) means that those words are chosen that will arouse sympathy and pleasure with the listener. Kato mancari lawan (words for finding enemies) are words that are pronounced to arouse antipathy and displeasure with the listener. Kurenah kata refers to the psychology of words. Kato iyo kato baturuik (saying 'yes' repeatedly) means that the words should be followed up. Kato tido kato mati (the word 'not' is the word 'death') means that there is agreement not to continue. Other words are bekarenah and may not be opposed, doubted, 
intended to having more meanings etcetera (Navis 1984: 98-104). Chart 2 shows the division of the oral Minangkabau culture.

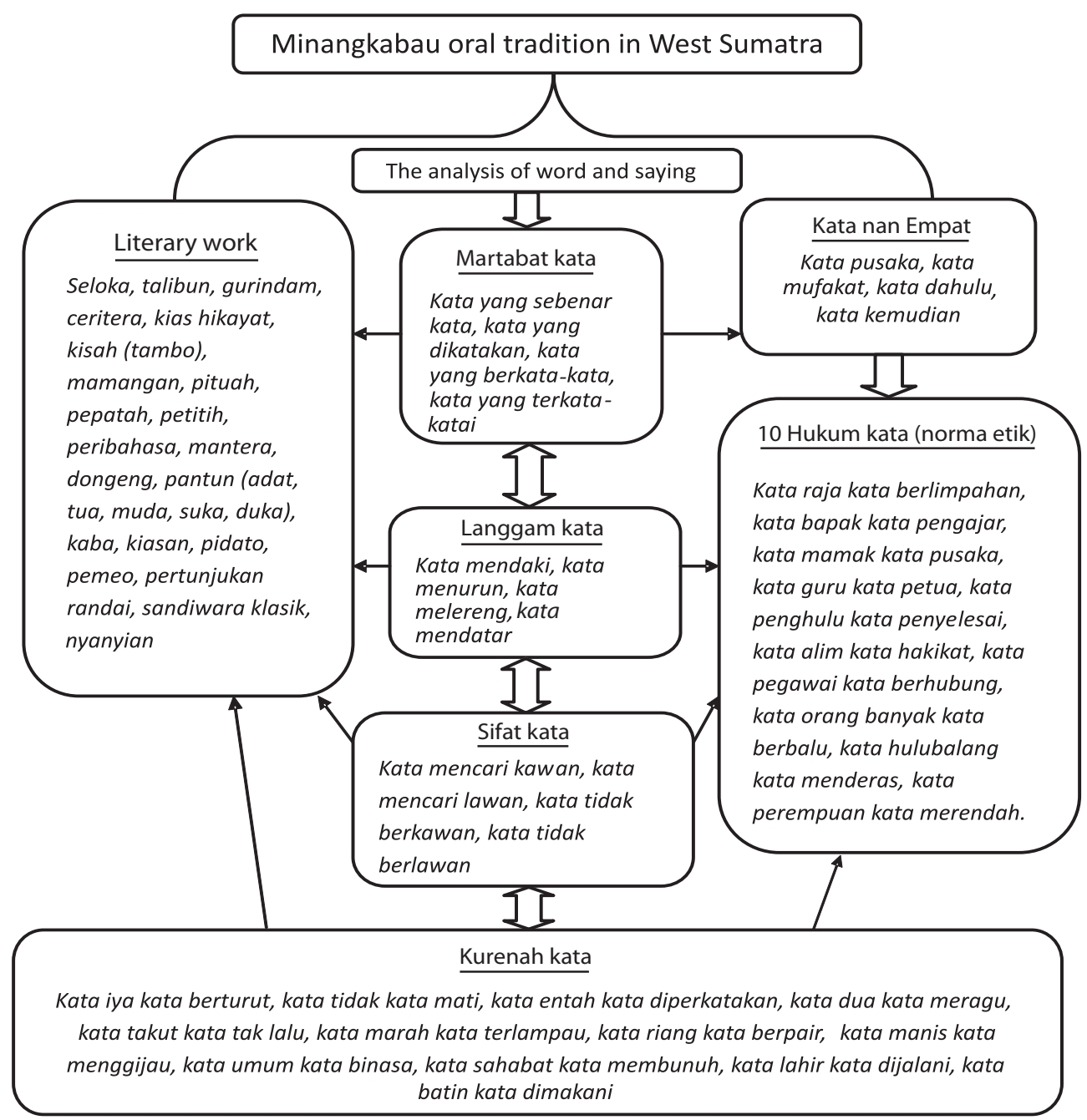

Chart 2. Minangkabau Oral tradition in west Sumatra.

\section{THE ORIGIN OF MINANGKABAU ORAL TRADITION}

In West Sumatra, oral tradition in the form of old sayings (pepatah) was inspired by an understanding of nature. This is mainly so because for Minangkabau society nature is everything. Man is born, lives, and dies in nature. Nature is absolute, exact, and cannot be transformed, and consists of the sun, moon, earth, stars, morning, afternoon, night, early morning, evening, north, west, south, fire, soil, and water (Navis 1984: 59, 256). Much like eternal customary law is expressed by means of pepatah: tidak lapuk karena hujan, tidak lekang karena panas. Rain and hot weather are natural phenomena that cause changes in the natural environment. Rain may cause wood to rot and erodes stone while 
heat can melt iron and causes water to evaporate. However, customary law is eternal and exceeds wood, stone, iron, and even water. The ideas it contains will not change because of the arrival of the rainy or hot seasons. Chart 3 shows the inspiration of the oral tradition in West Sumatra.

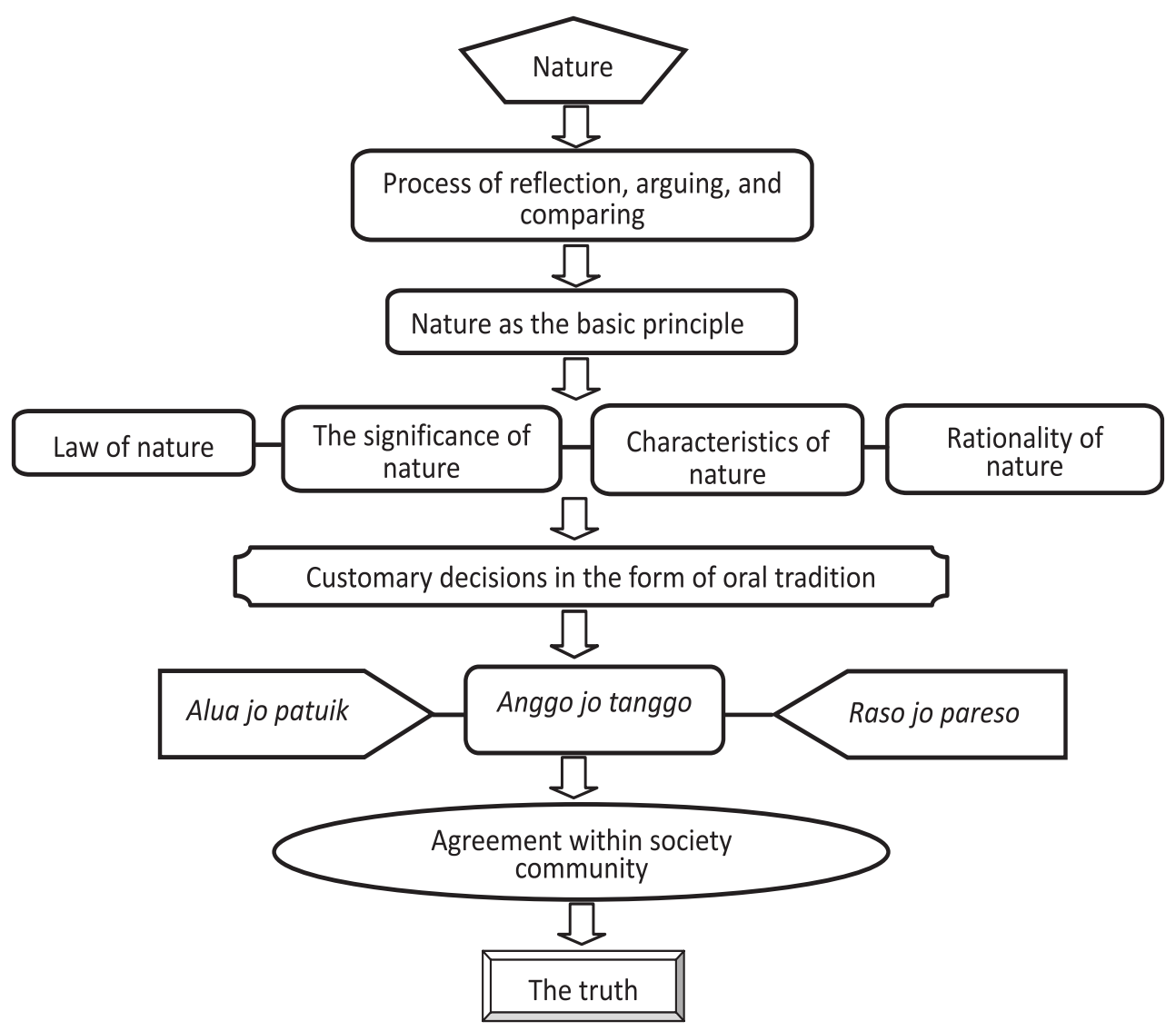

Chart 3. Nature as the source of inspiration for the oral tradition in West Sumatra.

As indicated in Chart 3, it is my understanding that the Minangkabau view nature as an existing reality that may inspire the activities and the thoughts of individuals, groups, and of society. Two prominent Minangkabau's persons, Datuak Katumanggungan and Datuk Perpatih Nan Sabatang (1165), turned to nature as the departure point in their creation of the fundaments of Minangkabau philosophy. The customary rules they proposed are still in use today. They engage in rational reflection, arguments, and comparisons in order to comprehend nature's purport taking from its teachings what they need and translating that into the fundaments of Minangkabau customs. This became the inspiration for the creation of the pepatah: nature as the source of inspiration (alam terkembang jadi guru). In ancient times, the characteristics of nature, natural law, and the understanding of nature were orally transmitted and only in the 1950s, the first book containing the findings of a study of various 
oral traditions in West Sumatra was published. ${ }^{3}$ Three kinds of customary rules were transmitted orally, alua jo patuik (the true and right path), anggo jo tango (rules that have to be obeyed) and raso jo pareso (feelings and conscious' whispers). Society's agreement with the customary rules is the source of the truth that prevails in Minangkabau society.

\section{PETATAH PETITIH IN THE STUDY OF ULAYAT LAND IN WEST SUMATRA}

Among the various kinds and styles of oral traditions in Minangkabau society, I would like to concentrate the discussion to one type of literary works in West Sumatra in relation to ulayat land. In Dutch, this land falls under communaal bezitsrecht (communal property right). The land is situated in a certain region and falls under the authority of a certain group of people who hold the right over the natural resources found in the area. Minangkabau society's continuing adherence to the rule of custom over ulayat land cases is illustrated in the sayings mostly uttered by the participants (members of society) on the issue.

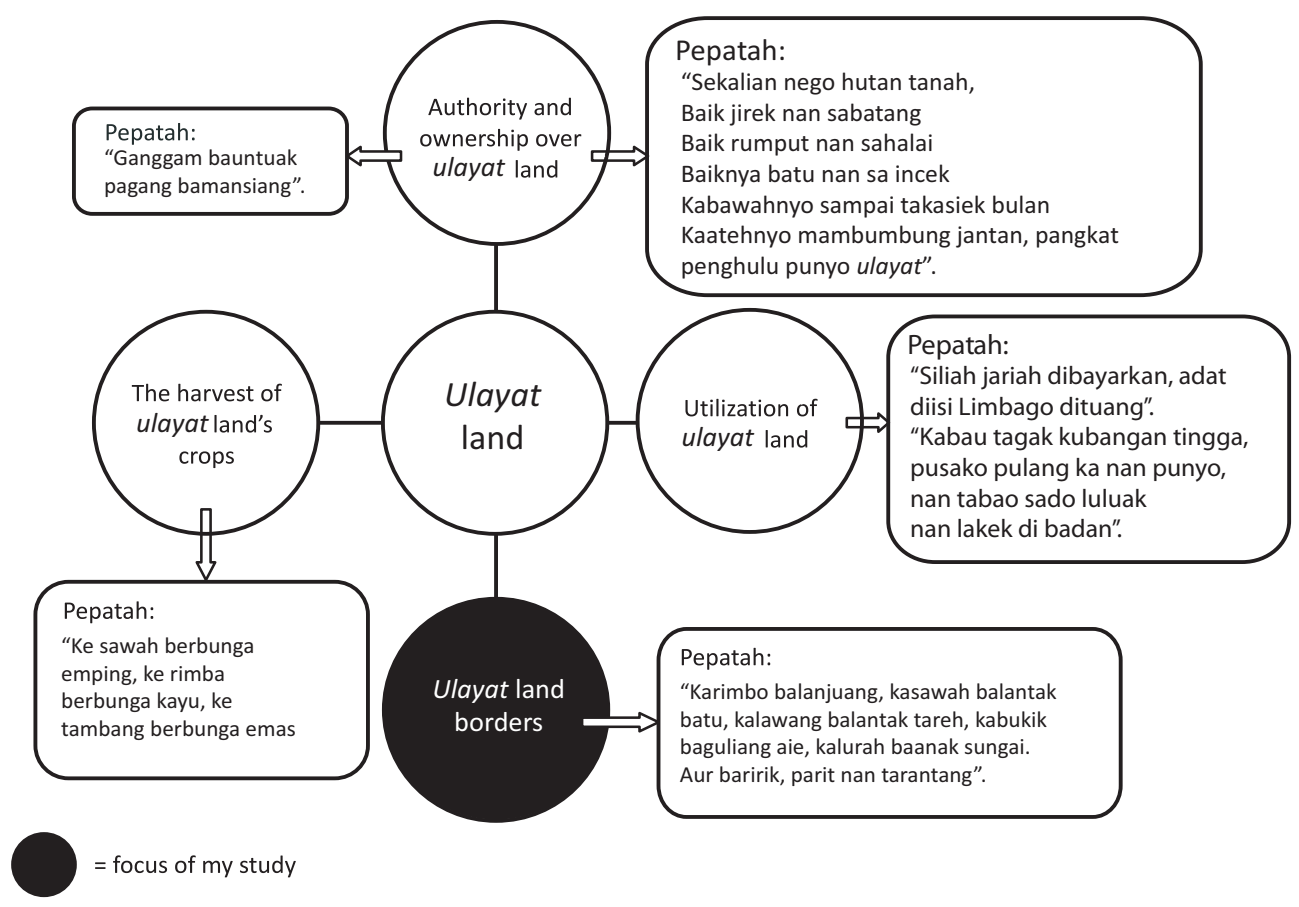

Chart 4 . The elements of ulayat land and their pepatah.

3 The book was written by the Minangkabau, Dt. Batuah Sango, about customary rules, entitled Tambo Alam Minangkabau and was published in 1954 in Payakumbuh. Earlier the Dutch M. Joustra had written a book entitled Minangkabau; Overzicht van land, geschiedenis en volk, published in 1923 ('s-Gravenhage: Nijhoff). 


\section{Authority and ownership over 'ulayat' land}

The authority over ulayat land by kaum, suku as well as Nagari is illustrated in the following pepatah:

Sekalian nego hutan tanah

Baik jirek nan sabatang

Baik rumput nan sahalai

Baiknyo batu nan sa incek

Kabawahnyo sampai takasiek bulan

Kaatehnyo sampai mambumbung jantan

Pangkat penghulu punyo ulayat
Everything grows on the land

Starting from a stick of jirak

Or a piece of grass

Or a piece of stone

All the natural richness contained on it

All of them are possessions of the

penghulu of the ulayat land

The pepatah shows that when a kaum, suku, or Nagari has the authority over ulayat land, everything that is on the land (and everything that grows on it, even though just jirak, grass, but also stone) is the property of the adat society. Similarly, adat society also owns everything that is located under its surface (sand, stone, wells, mine products) (Sjahmunir and Miko 2000: 56).

Ulayat land ownership is in the name of a group (suku, kaum, or Nagari), and not in the name of an individual. Nevertheless, every member of a kaum, suku, or Nagari is entitled to borrow the land for his own use. The individual use of ulayat land is made permanent in the pepatah: ganggam bauntuak, hiduik bapadok, pagang bamansiang (division which have been determined to right). They are entitled to build a house on it and to till the land and enjoy the fruits of their work. The utilization of ulayat land is regulated in regulations issued by the Mamak Kepala Waris/Mamak Kepala Kaum (the oldest man in tribe), with the condition that each family member rightfully owns his share of the land of his kaum.

\section{The utilization of 'ulayat' land}

In case ulayat land is used by someone who is not a member of adat society the following pepatah applies: jua indak di makan bali, gadai indak di makan sando. It implies that the land may not be sold or otherwise change into the hands of outsiders, but that the members of society are permitted to utilize, manage, cultivate as well as enjoy the fruit of the land. The regulation on the prohibition of selling or otherwise alienating of the land is formulated in the following pepatah:

Hak yang berpunya

Harta yang dimiliki

Hak yang tergantung

Milik adalah masing-masing

The regulations concerning the prohibition of trading in ulayat land is closely linked to the moral teaching that people of good morality are responsible for future generations (Perpatih Nan Tuo 1999: 5). This ensures that the 
relationship between Minangkabau society and ulayat land is unbreakable, a symbol of society's wealth and ensures the prosperity of future generations by opening up dry fields and wet rice paddies. This situation is illustrated in the following pepatah: ladang nan babintalak, sawah nan bapamatang, adalah pasak kungkung alam Minangkabau (farm, rice field, are the borders of the Minangkabau lands) (Soewardi 2004: 61-62).

When an outsider intends to utilize ulayat land, the following pepatah applies: siliah jariah dibayarkan, adat diisi limbago dituang. It means that a person who wants to utilize ulayat land of a Nagari, suku, or kaum has to hand over a sum of money as a token that he wishes to do so. When the period (previously agreed upon) to utilize the land has expired, the land returns to adat society abiding to the following pepatah: kabau tagak kubangan tingga, pusako pulang ka nan punyo, nan tabao sado luluak nan lakek di badan (the foreigner may take the result but land remains the property of customary society). Ulayat land is inalienable but the tiller of the land takes the fruits of his labour (Soewardi 2004: 65).

\section{The borders of 'ulayat' land}

According to the Tambo, authority over ulayat land began when the ancestors of a certain kaum opened up new land that had not been used before. Since they were the first to open up the land and to turn it into rice paddies or dry farmland, they were rightfully in charge of that land. The authority over the land was subsequently transmitted to next generations so that they could use it and thus it was called ulayat land. The pioneers constantly extended the land they tilled in order to increase their wealth reserves in order to pass it on to the next generations. Land that was already claimed was usually marked by planting a stone into the ground, or by placing a wooden sign and sturdy plants such as spiky bamboo (aur). The locations where the stone, wooden sign, or bamboo were put became the borders of a suku or kaum's landownership. Ulayat land borders were also indicated by natural boundaries available in each kaum, suku, and Nagari, following the pepatah: karimbo balanjuang, kasawah balantak batu, kalawang barantak tareh, kabukik baguliang aie, kalurah baanak sungai, aur baririk parit nan tarantang (jungle, rice field, dale, hill, river, a spiky bamboo and a dugged ditch are the borders of the ulayat lands). The placement of these border signs at the designated places are done by the Mamak Kepala Waris (Navis 1984: 53).

\section{The harvest of the fruit of the land}

The harvest of the crops grown on ulayat land follows the pepatah: ke sawah berbunga emping, ke rimba berbunga kayu, ke tambang berbunga emas (rice fields yield paddy, jungle yield wood, mine yield gold). The penghulu receives some benefit when a group of people/families turn ulayat land into rice paddies, dry farmland, or a pond. This situation is illustrated in the following pepatah: adat bunga tanah (advantage of farm result), adat tanam batu (boundary is 
stone). It means that the penghulu who owns the ulayat land indicates the boundaries of that part of the land that may be cultivated or exploited. The technical term is watas pasu padannya and pieces of wood indicate the borders of the land that may be used for dry farmland or for mining purposes. This role is in conformity with adat takuk kayu (boundary is wood). Another way of indicating is by putting a stone in the ground which explains the name adat tanam batu. After the land has been opened up or made ready for mining, the penghulu will receive ten percent of the total produce and this role conforms to the adat bunga tanah (advantage of farm result presented to the land owner) (Datoek Toeah 1989: 238).

\section{ULAYAT LAND CONFLICTS IN WEST SUMATRA}

In 2008, 132 suits were launched to the West Sumatra Representation of the National Committee for Human Rights of which 85 percent concerned ulayat land cases. ${ }^{4}$ This agrees with the data of the National Land Board (Badan Pertanahan Nasional, BPN) of West Sumatra which states that land conflict cases are found all over West Sumatra and that they show an increase. In 2008, the BPN noted 637 cases while three months later, begin March 2009 the number had risen to 677. This situation is troublesome to many and has led me to wonder why ulayat land conflicts persist and why they are so difficult to solve.

\section{THE CHRONOLOGY OF CONFLICTS AND THEIR RELATION TO ORAL TRADITION}

Based on field and literature research (May 2009) about two Nagari that were involved in ulayat land disputes, Nagari Sumpur and Nagari Bungo Tanjung situated on the Tanah Datar area, West Sumatra Province, I discovered that one of the main reasons for the conflict was the different perception parties have on ulayat land ownership and borders as based on the pepatah: aur baririk, parit nan tarantang. This pepatah is understood as the border between the ulayat land of the two adjacent Nagari Sumpur and Nagari Bungo Tanjung. ${ }^{5}$ Aur baririk means spiky bamboo, which was purposefully planted by the ancestors to indicate the boundary of authority and ownership of these ulayat lands. This bamboo usually has three shoots so that the line that connects the three shoots is called aur nan baririk (bamboo shoots in formation). Planting the bamboo not being enough, both ancestors of the two Nagari also agreed to dig a ditch in the ground in which they dug iron to designate the ulayat border. This

4 Data derived from reports from the West Sumatra Representation of the National Committee for Human Rights.

5 Nagari Sumpur and Nagari Bungo Tanjung are part of two different districts, namely Batipuh and Batipuh Selatan. The people in Nagari Sumpur belong to a different governance system than those of Nagari Bungo Tanjung. Nagari Sumpur originates from the governance system Bodi Caniago while Nagari Bungo Tanjung's governance system is Koto Piliang. Nagari Sumpur is situated on the western shore of Danau Singkarak while Nagari Bungo Tanjung is located in the mountains surrounding Danau Singkarak. 
agreement was made around 1800. Since then, the penghulu of the two Nagari tried to orally socialize the next pepatah: tutur nan dijawab, waris nan ditarimo (the spoken word is reciprocated, the inheritance is received in acceptance).

When the Dutch colonizers arrived in Indonesia, they issued an occupation map of the area in the interests of Dutch rule on which the Nagari borders were indicated. ${ }^{6}$ According to Kerapatan Adat Nagari (KAN) Sumpur, witnessed by the assistance resident of Luhak Batipoeh X Koto on 20 October 1896, the two Nagari (Nagari Sumpur and Nagari bungo) agreed with the map the Dutch produced, based on aur baririk parit nan tarantang. Sumpur is convinced that this is the first written proof and therefore forms the ground for the validity of the ulayat land borders between the two Nagari.

Since 1954, the border area has started to develop when people from Bungo Tanjung (Jorong Kapuh) began to settle there and started to use the land for cultivation. Because the population in Bungo Tanjung was denser than that in Sumpur, Sumpur claims that around ten hectare of its ulayat land was rented by farmers from Kapuh which was part of the Bungo Tanjung area. ${ }^{7}$ In 1954, Sumpur producted nine rent agreement contract from nine farmers who used Nagari Sumpur ulayat land. This situation continued over the following years, $1956,1967,1987$ (renting contract), 1988, and lastly 1989. There are as many as 20 letters that constitute the second written proof that the land is owned by the adat people from Nagari Sumpur. As stipulated in these written documents, the people who were originally from Jorong Kapuh always paid rent which amounted to ten percent of the total crops which became a source of income for Nagari Sumpur.

After Indonesian Independence, on 8 February 1955 Sumpur restated the border separating the ulayat of the two Nagari by a letter from the local government of Tanah Datar or the Temporary Dictum of the Regent/Head of the Tanah Datar Regency number 1 / 1955 dated 3 September 1955 concerning the Agreement on the ulayat lands borders between the two Nagari. For Sumpur, this is the third written proof reinforcing the argument that the land being rented by Jorong Kapuh is truly Nagari Sumpur ulayat property. ${ }^{8}$

In 1989, a group of Kapuh farmers discontinued to pay the rent to Nagari Sumpur. They took this action on the suggestion of the Chairman of the KAN of Bungo Tanjung and of various Datuk. The reason was that the first written proof, the Dutch occupation map was not based on the pepatah: aur baririk parit nan tarantang. On the map, all the borders between the Nagari are indicated

6 Maps 28-29-30-34 and 94, of a Dutch East Indies topographical map made between 1886 and 1896.

7 The mere fact that Kapuh farmers entered the Sumpur area caused controversies. Sumpur said that the ancestors of the Kapuh farmers were leprosy exiles banned to places high up in the hills and that they ultimately rented Nagari Sumpur land. The Kapuh people deny this and say that their ancestors ordered them to use the ulayat land of their own Nagari, namely Bungo Tanjung.

Photocopies of the map, the nine rent contracts, the letter from Tanah Datar local residence number 1/1955 dated as 3 September have been analysed for this research and are on file with the author. 
by straight lines whereas the borders of the ulayat lands follow the curving contours of the hilly land. It means that the Dutch map cannot possibly be based on aur baririk parit nan tarantang. Bungo Tanjung has its own sketch of the map that shows that the land the Kapuh farmers use is actually their own ulayat land. The sketch (which is undated and anonymous) owned by Bungo Tanjung clearly indicates the location of the aur baririk their ancestors planted to indicate the border between the ulayat lands. The controversy about the location of the aur baririk versus the Dutch map became the origin of the prolonged conflict between the two Nagari.

Bungo Tanjung does not accept the validity of the 20 rental contracts signed by the farmers from Kapuh and Kerapatan Adat Nagari (KAN) based on the argument that they were made under duress (witnesses were still alive) and even their authenticity was questioned since they are not the originals. Below follow excerpts from an interview I had with an interviewee from Bungo Tanjung:

The rental agreements are invalid because they were made under duress and the ninik mamak had not notified the penghulu kaum. The land over which money has been paid to Sumpur is Bungo Tanjung's own ulayat land. From way back, the land was in possession of seven penghulu from Nagari Bungo Tanjung. The natural borders that attest that this is Nagari Bungo Tanjung property is the aur nan baririk, parit nan tarantang. Up to now, the spiky bamboo is still there and also there are still remains of the ditch that was dug by the earliest penghulu. However, some farmers were pressurized and were forced to sign the rental agreements. ${ }^{9}$

The informant related some incidents telling of Kapuh farmers' fear each time the Karapan Adat Nagari Sumpur came to collect the rent. There were repeated violent incidents such as the murder of a Kapuh farmer in 1922. It was only in 1989 that the farmers dared to follow the suggestion of the Jorong Kapuh representative no longer to pay the rent to Sumpur.

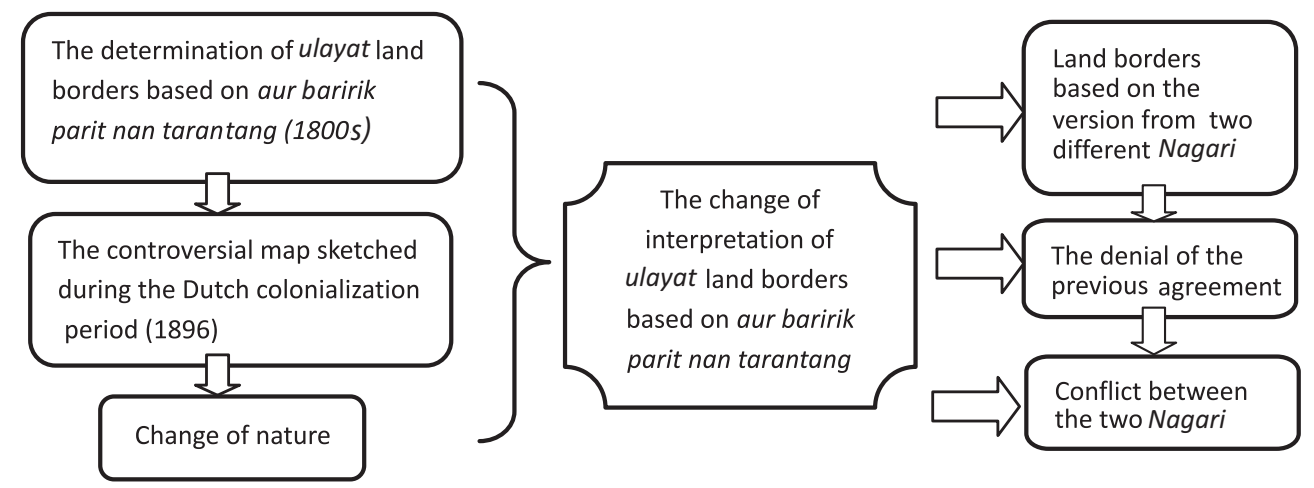

Chart 5. Conflict between Nagari Sumpur and Bungo Tanjung.

9 Because the conflict is still ongoing, I purposefully hid the identity of my interviewees from both Nagari. The interviews were conducted with these people from Bungo Tanjung on 18 May 2009 at their residence at 02.00 am at Lubuk Buaya Padang. 
In order to invalidate Sumpur's written proof, Bungo Tanjung adat figures collected various written statements from other neighbourhood Nagari, such as Nagari Padang Laweh and Desa Pincuran Tujuh. They stated that Nagari Padang Laweh is the border to the south of Bungo Tanjung, Desa Pincuran Tujuh in the west, Sumpur in the east and on the north the ulayat land of kaum Bungo Tanjung. The most authoritative statement on this matter came from Desa Pincuran Tujuh. It said that the ulayat land of kaum Jambak borders on Jorong Kapuh, and not on Nagari Sumpur. This statement nullifies Sumpur's authority over the 10 hectars of land occupied by Jorong Kapuh. ${ }^{10}$ Based on the short exposition stated above, Chart 5 presents a chart of my own analysis of the conflict.

\section{IS ORAL TRADITION THE CAUSE OF THE CONFLICT?}

The result of the different perception of the location of the ulayat land based on the pepatah: aur baririk parit nan tarantang is a conflict where Nagari Sumpur accused Nagari Bungo Tanjung of breaking the agreement over the border of the ulayat lands made by their ancestors, of denying the validity of the rental agreements, and of causing losses of income because the farmers refuse to pay any more rent. Simply said, Sumpur accused Bungo Tanjung of seizing and utilizing ulayat land owned by Nagari Sumpur. Bungo Tanjung' accusation is no less pointed. They insist on accusing Sumpur of perpetrating criminal acts each time they come to collect the rent and by doing so using force and threats. They also accuse Sumpur of having plotted with the Dutch in order to change the borders the ulayat lands based on the aur baririk parit nan tarantang. The hostility and hate between the elites of the two Nagari has spilled over to the rest of society and may well escalate into a large-scaled conflict.

As mentioned above, in the 1800s, it was very common for ancestors from the two Nagari to determine their land borders by simply referring to aur baririk parit nan tarantang. This saying was actually well-adapted to the existing natural phenomenon at the time. Based on the reason that these natural phenomena were considered the most observable and discernable, they were agreed to be the legal borders between the lands. Unfortunately, natural conditions are prone to changes as a result of earthquakes, wind storms and the movement of the layers of the soil. Over the next 100 years, the saying has become invalid. Thin bamboo as a living plant may also perish because of natural processes or may regenerate into new plants on other locations. The ditch that was constructed in the 1800s may have filled up with soil or have become covered by plants growing on and over it. Therefore, the ditch as the legal land boundary is no longer discernable. Noticing these facts, the author argues that presently, it makes little sense to retain aur baririk parit nan tarantang as the base for discovering the borders of the land. Although these natural changes have caused the decreased validity of aur baririk parit nan tarantang, the people still defend their argument that this oral tradition exists. The root 
of the conflict is therefore the difference in perception about the position of the aur baririk parit nan tarantang between the two Nagari.

This brings me to the conclusion that oral tradition, especially the pepatah: aur baririk parit nan tarantang as the recognized basis for the determination of the exact locations of ulayat land borders of has flaws. These flaws became evident when I discovered that various contradictive oral and written data (the oral ones were usually gathered during interviews) both parties used in the conflict. I consider these controversial findings the weakness of the oral tradition to which local society in west Sumatra still strongly adheres. The weak points of this oral tradition may be summarized as follows:

1. The trustworthiness of the oral tradition is not substantiated by reliable data. All the evidence proposed by both Nagari are mutually contradictory and often one piece of evidence is overruled by another. The author had difficulty in judging which evidence from which party was the most reliable. The validity of either oral or written documentation has to be established by legal procedures and under specific conditions in order to be recognized as the truth. I limited myself to data collections and to analyse the controversies among them, and lastly by studying the philosophical aspect that forms the basis of one specific kind of behaviour in society. I did not study the evidence put forward by both interested parties since this requires analysis by a legal expert.

2. Oral tradition opens the possibility to disadvantage the other party for the sake of certain objectives. On the surface, the land conflict is inspired by a clear economic motive. For Nagari Sumpur the case must be won because that will give them back their income from letting the land to farmers from Kapuh (which they had paid since 1954). Bungo Tanjung and especially the Kapuh farmers who so far had paid one tenth of the value of the crops to Sumpur also had an interest in keeping and enjoying the fruit of their hard work. Both parties thus put in every effort to win the conflict because it is directly related to their income.

3. There is a possibility to redirect ulayat land borders. As both Sumpur and Bungo Tanjung are in the possession of a sketched map of the borders of their ulayat land, accusations were made that the other party had moved the border of their ulayat land based on their version of the map. Who had moved these borders was unknown, but the act was clearly a criminal cultural one that had a negative impact on various aspects of life. Other cultural criminal acts were that some people sold or rented out ulayat land unilaterally. When I asked who those people were, they hid their evidence in order to protect their good name (this kind of accusations emerged from gossip without any concrete proof).

4. The perpetrators of this conflict took a negative way of looking at things by forgetting, providing inaccurate information, subjectivity, chauvinist with of their oral tradition and exonerating their attitude by hiding behind the pepatah: tutur nan dijawab, waris nan diterima (the spoken word is reciprocated, the inheritance is received in acceptance) and by being 
disinclined/lazy to enter into important agreements in writing. Those who knew the facts did not want to provide explanations because they did not have any proof or witnesses. For me, the most damaging characteristic is that they denied the validity of written facts. From the two parties in the conflict, I obtained more written data from Sumpur than from Bungo Tanjung. However, since oral tradition had developed among society, Bungo Tanjung denied various facts by referring to the oral tradition they have faith in such as the pepatah: tutur yang dijawab waris yang ditarimo.

\section{CONCLUSION}

In conclusion, the oral tradition concerning ulayat land borders is in various aspects no longer credible, the more so in the absence of written support. Merely relying on oral tradition without ever clearly remapping the ulayat borders will potentially result in conflict. Ironically, almost all of the Nagari in West Sumatra (534 in number) do not have clear borders and continue to rely on oral tradition (pepatah) transmitted to them from their ancestors. When a conflict occurs, the people adopt a negative attitude by hiding behind their oral tradition in order to justify their opinion and their way of behaviour while at the same time using it to denounce the other. The result is that today, it is impossible to use the adat pepatah: aur baririk parit nan tarantang as the basis for the ulayat land borders because it is no longer clear which aur or what parit should be regarded as borders.

In order to settle the conflict I suggest that a remapping of the ulayat land borders should be preceded by negotiations between both parties. The result of the negotiations should be written down jointly and made up into a drawing to avoid future misunderstanding. Based on experience, efforts to solve conflicts like negotiations never provide a solution if parties do not give up their argument. In May 2009, a nonprofit non-governmental organization, LSM Qbar tried to facilitate negotiations between the two parties and has continued to do so until the day I ended my field research. I would also suggest that both parties involved in the conflict to propose this problem to the Badan Pertanahan Nasional (BPN, the National Land Board), as the national agency responsible for handling these kind of land cases. The recent advertisement displaying a quarrel between two persons who are disputing over a land boundary in the form of a jengkol tree provides an excellent illustration of the contemporary land conflict between Nagari Bungo Tanjung and Nagari Sumpur. Hopefully, LSM Qbar's efforts and appeals from BPN to have a certificate drawn up will wake up the people that modern agreements and settlements have to be in writing.

\section{REFERENCES}

Amir M.S. 1997. Adat Minangkabau; Pola dan tujuan hidup orang Minang. Jakarta: Mutiara Sumber Widya.

Bakar, Jamil et al. 1981. Sastra lisan Minangkabau: pepatah, pantun, dan mantra. Jakarta: Pusat Pembinaan dan Pengembangan Bahasa, Departemen 
Pendidikan dan Kebudayaan.

Datoek Toeah. 1989. Tambo Alam Minangkabau. Edited by A. Damhoeri. Bukittinggi: Pustaka Indonesia.

Navis, Ali Akbar. 1984. Alam terkembang jadi guru; Adat dan kebudayaan Minangkabau. Jakarta: Grafiti Pers.

Perpatih Nan Tuo, Nurullah H. Dt. 1999. Tanah Ulayat menurut ajaran adat Minangkabau. Padang: Yayasan Sako Batuah LKAAM.

Soewardi, Idris. 2004. Sekitar adat Minangkabau. Jakarta: Kulik-kulik Alang. Sjahmunir, A.M and Alfan Miko (eds). 2000. Pemerintahan Nagari dan tanah ulayat. Padang: Andalas University Press. 